\title{
Effect of different dolomitic limestone dosages on soil respiration in a mid-altitudinal Norway spruce stand
}

\author{
Jana Rosíková (1), \\ Eva Darenova (2), \\ Aleš Kučera ${ }^{(1)}$, \\ Daniel Volařík ${ }^{(3)}$, \\ Valerie Vranová ${ }^{(1)}$
}

The study focuses on the effect of chemical amelioration of dolomitic limestone (doses of $0,2,3,4,6,9$ and $26 \mathrm{t} \mathrm{ha}^{-1}$ ) on soil respiration in a Norway spruce monoculture in mid-altitudinal elevation during one-year period after application. Firstly, the soil respiration was measured in situ as monthly $\mathrm{CO}_{2}$ efflux from the soil surface horizon in the period May to October 2016. Secondly, basal respiration, microbial biomass carbon and metabolic quotient of the organic $\mathrm{H}$ and organo-mineral A horizons were assessed under laboratory conditions within one year after the treatment. Soil $\mathrm{CO}_{2}$ efflux increased by 3 to $31 \%$ and by 29 to $98 \%$ for the ameliorant of 2 and $26 \mathrm{t} \mathrm{ha}^{-1}$, respectively, compared to the unlimed control treatment. The $\mathrm{CO}_{2}$ efflux was significantly driven by external conditions such as soil moisture and temperature, especially in the last seasonal months. Basal respiration of the $\mathrm{H}$ horizon increased up to a dose of $9 \mathrm{t} \mathrm{ha}^{-1}$ but decreased at $26 \mathrm{t} \mathrm{ha}^{-1}$. In the A horizon, microbial activity increased in all the limed variants compared to the non-limed variant. A similar trend was observed in microbial carbon and the metabolic quotient of the soil. Our results prove that the ameliorant doses commonly used in the forestry sector (3-4 $\left.\mathrm{tha}^{-1}\right)$ substantially increase the soil microbial activity during (soil $\mathrm{CO}_{2}$ efflux) and after (laboratory data) the first year after application. This results in the accelerated mineralization of soil organic material and subsequent loss from the forest ecosystem.

Keywords: Amelioration, Basal Respiration, Liming, Picea abies, Soil $\mathrm{CO}_{2}$ Efflux

\section{Introduction}

Lime treatment of forest stands has had a fairly long history in Central Europe (Seibt 1977). Historically, lime was used to reduce soil acidification as a negative effect of acidic deposition; it is currently used as a

(1) Mendel University in Brno, Faculty of Forestry and Wood Technology, Department of Geology and Pedology, Zemedelska 3, 61300 Brno (Czech Republic); (2) Global Change Research Institute, Academy of Sciences of the Czech Republic, Belidla 4a, 60300 Brno (Czech Republic); (3) Mendel University in Brno, Faculty of Forestry and Wood Technology, Department of Forest Botany, Dendrology and Geobiocoenology, Zemedelska 3, 61300 Brno (Czech Republic)

\section{@ Jana Rosíková}

(jana.rosikova@mendelu.cz)

Received: Jun 11, 2018 - Accepted: Apr 13, 2019

Citation: Rosíková J, Darenova E, Kučera A, Volarík D, Vranová V (2019). Effect of different dolomitic limestone dosages on soil respiration in a mid-altitudinal Norway spruce stand. iForest 12: 357-365. - doi: 10.3832/ifor2894-012 [online 2019-07-05]

Communicated by: Rossella Guerrieri method of supplying the missing nutrients that are blocked in the forest floor (Srámek et al. 2014a). Liming in the Czech Republic reached the highest intensity during the air pollution crisis in the 1970 s and 1980 s (Hunová \& Ostatnická 2004). In particular, it was applied on mountain areas of the Czech borders in the dose of $3 \mathrm{t} \mathrm{ha}^{-1}$ (Srámek et al. 2014b). Within the early $21^{\text {st }}$ century, liming was also targeted to mid-altitudinal forests to improve nutrient supply. In addition to the well-known immediate effects of liming on soil pH and nutrient supply, liming widely influences many aspects of the soil environment, which have not been well identified so far (Paradelo et al. 2015, Binkley \& Högberg 2016), such as mineralization rate, microbial biomass, metabolic quotient, etc. However, while liming may only be a temporary solution, it is still commonly applied.

Liming results in a number of alterations, mostly in topsoil (Frank \& Stuanes 2003). Liming influences the soil sorption complex by increasing the base saturation (Löfgren et al. 2009), especially via bivalent base cations $\left(\mathrm{Ca}^{2+}\right.$ and, in case of dolomitic limestone use, $\mathrm{Mg}^{2+}-$ Hindar et al. 2003), and increasing of $\mathrm{pH}$. Nevertheless, liming involves risks brought about by antagonism with potassium $\left(\mathrm{K}^{+}\right)$, which is susceptible to leaching and blocked for nutrition availability (Weis et al. 2009) and organic matter mineralization. The latter one results from an increase in microbial activity and influ- ences the soil water regime and water retention capacity (Moravčík \& Cienciala 2005), mineral nutrient mobilization (Saarsalmi et al. 2011) and nitrogen dynamics (Corre et al. 2003). Liming can also end in the redistribution of fine roots towards the topsoil, which especially in Norway spruce forests (Kakei \& Clifford 2002) increases the risk of drought stress (Majdi \& Viebke 2004) and uprooting.

The influence of liming on soil chemistry is manifested by edaphon functional group composition and biological activity ( $\mathrm{Pa}$ radelo et al. 2015). An increase in bacterial populations leads to a decrease in the fungi-to-bacteria ratio (Bååth \& Anderson 2003) and an increase in the mineralization intensity of organic matter, which can be measured as a release of nutrients and increase in soil respiration/ $/ \mathrm{CO}_{2}$ efflux (Huber et al. 2006). The response of soil biota to liming can be assessed by monitoring of soil respiration (Nilsson et al. 2001), microbial biomass carbon and metabolic quotient reflecting energy maintenance (Aye et al. 2016). The soil microbial activity is closely related to temperature and moisture (Berryman et al. 2015), thus it can be presumed that the effect of liming will differ under the influence of climate when measured in the field.

Some studies (Augusto et al. 2002, Lee et al. 2007, Binkley \& Högberg 2016) found liming as an ambiguous, temporary but rather effective amelioration management. 
Only a few studies in the literature deal with the influence of liming on soil biota; therefore, a critical question regarding the significance of liming on soil respiration and related parameters is still unsolved. Indeed, soil biota response is estimated rather than precisely measured and the response will probably differ according to doses of the ameliorant, especially using extreme amounts.

The aim of the study is to quantify the effect of liming on the biological activity of topsoil in relation to the different doses of dolomitic limestone $(0,2,3,4,6,9,26 \mathrm{t}$ $\left.h^{-1}\right)$. The hypotheses were the following: (1) soil respiration will increase after liming; and (2) this effect will increase with a limestone dosage.

The respiration was measured (i) in situ as $\mathrm{CO}_{2}$ efflux from the soil surface monthly from May to October 2016 in the year following the application of the ameliorant (November 2015); and (ii) in the laboratory as soil basal respiration using gas chromatography at one year after applying the ameliorant. As supplementary data, the microbial biomass carbon and metabolic quotient were determined. The study is unique from the point of view of the following aspects: (1) the mid-altitudinal elevations (previous studies focused on mountain forests); (2) the wide range of doses of the ameliorant; and (3) the high number of selected investigated parameters (in situ soil $\mathrm{CO}_{2}$ efflux, soil moisture and temperature, basal respiration, microbial biomass carbon, metabolic quotient, soil $\mathrm{pH}$ ).

\section{Materials and methods}

\section{Site description}

The experimental plots were established at the Field Research Station Rájec-Němčice, Drahanská vrchovina region (Czech Republic - $49^{\circ} 26^{\prime} 32^{\prime \prime} \mathrm{N}, 16^{\circ} 41^{\prime} 52^{\prime \prime} \mathrm{E} ; 623 \mathrm{~m}$ a.s.l.; flat terrain; moderately warm and humid climate; mean annual temperature 8.15 ${ }^{\circ} \mathrm{C}$; mean annual precipitation $631 \mathrm{~mm}$ ). Ac- cording to the FAO classification system (IUSS-WRB 2015), the soil was classified as Haplic Cambisol with acid granodiorite as bedrock. Potential vegetation in terms of forest site complexes (Viewegh et al. 2003) was classified as Fagetum mesotrophicum (nutrient-medium Beech); actual vegetation is composed of $100 \%$ Norway spruce monoculture (Picea abies [L.] H. Karst) aged 110 years with $70-75 \%$ coverage in the first generation and with 30\% undergrowth coverage of Small balsam (Impatiens parviflora).

In November 2015, the study plot was sampled prior to the treatment. The soil was characterized by extremely acidic $\mathrm{pH}$ and unsaturated soil sorption complex (Tab. 1). The $\mathrm{H}$ humus horizon thickness was $3.0-4.5 \mathrm{~cm}$, the A organo-mineral horizon thickness was $1.5-2.5 \mathrm{~cm}$, stock of organic matter in the surface organic horizons was $94.05 \mathrm{t} \mathrm{ha}^{-1}$ on average (standard deviation = 19.65).

\section{Experimental design and soil sampling}

The homogeneous $35 \times 20 \mathrm{~m}$ experimental plot was divided into 7 sampling subplots of $5 \times 20 \mathrm{~m}$, which were mutually isolated using PVC foil to the depth of $50 \mathrm{~cm}$. Each subplot was spread with a different dose of finely ground dolomitic limestone (the doses of $0,2,3,4,6,9,26 \mathrm{t} \mathrm{ha}^{-1}$ ). The doses of 2, 4 and $6 \mathrm{t} \mathrm{ha}^{-1}$ were used to monitor the soil response near the standard dose of 3 t ha $^{-1}$ (Srámek et al. 2014a, 2014b); the doses of 9 and $26 \mathrm{t} \mathrm{ha}^{-1}$ were used to study soil response under the extremely high amounts of the ameliorant. At each subplot, in the longitudinal axes, seven PVC rings were pre-installed for the duration of the experiment $(15 \mathrm{~cm}$ high, embedded 3 $\mathrm{cm}$ deep in the soil; 49 rings in total) at the distance of $3 \mathrm{~m}$ to measure $\mathrm{CO}_{2}$ efflux (see below).

One year after liming (November 2016), a total of 21 soil samples were taken both from the horizons $\mathrm{H}$ (organic horizon of humification) and A (organo-mineral hori-

Tab. 1 - Selected soil properties characterizing the initial state in horizons $\mathrm{H}$ and $\mathrm{A}$ November 2015. (sd): standard deviation; $(\mathrm{n})$ : number of repetitions; $\left(\mathrm{pH} / \mathrm{H}_{2} \mathrm{O}\right)$ : active soil $\mathrm{pH}$; $(\mathrm{pH} / \mathrm{KCl})$ : exchangeable soil $\mathrm{pH}$; (Corg): organic (oxidizable) carbon content; (Cmic): microbial biomass carbon; (BasResp): basal respiration; $\left(\mathrm{qCO}_{2}\right)$ : metabolic quotient; (CEC): cation exchange capacity; (BS): base saturation; $(\mathrm{C} / \mathrm{N})$ : carbon-to-nitrogen ratio; (dw): dry weight.

\begin{tabular}{llrrrr}
\hline \multirow{2}{*}{ Variable } & \multirow{2}{*}{ Units } & \multicolumn{2}{c}{ H horizon $(\mathbf{n}=\mathbf{1 3})$} & \multicolumn{2}{c}{ A horizon $(\mathbf{n}=\mathbf{1 1})$} \\
\cline { 3 - 6 } & & mean & sd & mean & sd \\
\hline $\mathrm{pH} / \mathrm{H}_{2} \mathrm{O}$ & - & 3.41 & 0.12 & 3.42 & 0.04 \\
$\mathrm{pH} / \mathrm{KCl}$ & - & 2.81 & 0.15 & 2.61 & 0.06 \\
$\mathrm{Corg}$ & $\%$ & 32.24 & 2.75 & 9.77 & 0.9 \\
\hline $\mathrm{Cmic}$ & $\mu \mathrm{g} \mathrm{C} \mathrm{g} \mathrm{dw}^{-1}$ & 1261.94 & 131.84 & 282.22 & 68.64 \\
$\mathrm{BasResp}$ & $\mu \mathrm{g} \mathrm{C}-\mathrm{CO}_{2} \mathrm{~h}^{-1} \mathrm{~g}^{-1} \mathrm{dw}$ & 3.52 & 0.55 & 1.31 & 0.19 \\
$\mathrm{qCO}_{2}$ & $\mu \mathrm{g} \mathrm{C}-\mathrm{CO}_{2} \mathrm{mg}^{-1} \mathrm{Cmic} \mathrm{h}^{-1}$ & 2.8 & 0.5 & 4.9 & 1.1 \\
$\mathrm{CEC}$ & $\mathrm{cmolc} \mathrm{kg}^{-1}$ & 36.42 & 2.52 & 34.61 & 0.89 \\
$\mathrm{BS}$ & $\%$ & 17.67 & 3.11 & 8.26 & 1.13 \\
$\mathrm{C} / \mathrm{N}$ & $\%$ & 23.46 & 2.06 & 31.73 & 2.99 \\
\hline
\end{tabular}

zon), 3 from each lime treatment variant for the $\mathrm{H}$ and $\mathrm{A}$ horizons. The samples were sieved through a 2-mm sieve and conserved fresh at $4{ }^{\circ} \mathrm{C}$ for the time period of two weeks prior to laboratory analysis (assessment of basal respiration and microbial biomass carbon); the soil samples were airdried and sieved through a 2-mm sieve for the subsequent assessment of $\mathrm{pH}$.

To avoid measuring any $\mathrm{CO}_{2}$ incoming from the $\mathrm{CaCO}_{3}$ chemical dissolution, we verified the presence/absence of free carbonates in the soil using volumetric quantification with $4 \mathrm{~mol} \mathrm{HCl}$ according to ISO10693 (1995).

\section{Measurement of soil $\mathrm{CO}_{2}$ efflux in situ and expression of $R_{10}$}

In the time period May to October 2016, soil $\mathrm{CO}_{2}$ efflux was measured from 08:00 to 11:00 a.m. at the end of every month. The $\mathrm{CO}_{2}$ efflux was measured using a portable system LI-COR LI-8100A ${ }^{\oplus}$ (Li-Cor, Lincoln, $\mathrm{NE}$, USA) with a 20-cm-diameter chamber, fitted on the pre-installed PVC rings. After closing a chamber, a period (dead band) of $15 \mathrm{~s}$ was set to allow steady mixing of the air in the chamber. During the following 60 $\mathrm{s}$, the $\mathrm{CO}_{2}$ concentration was measured repeatedly at 1-s intervals, and a linear approach was used to calculate the soil $\mathrm{CO}_{2}$ efflux.

During each measurement, the soil temperature $\left({ }^{\circ} \mathrm{C}\right)$ at $1.5 \mathrm{~cm}(\mathrm{TPD} 32$ penetrate thermometer, Omega, Stamford, CT, USA) and soil moisture (\%vol) in the $0-6 \mathrm{~cm}$ profile (ThetaProbe $M L 2 x^{\oplus}$, Delta-T Devices, Cambridge, UK) were measured at a distance of $5 \mathrm{~cm}$ outside the PVC ring for a minimum of three points for each measurement position.

Within the forest stand close to the experimental plots, the continuous measurements of soil $\mathrm{CO}_{2}$ efflux were carried out applying an automated closed (non-steadystate through-flow) system (developed at the Global Change Research Institute in Brno, CZ) with six chambers. The design and installation were described by Darenova et al. (2016). Within each chamber, the soil temperature (thermometers PT-100 ${ }^{\circledR}$, Treston a.s., $\mathrm{CZ}$ ) was measured simultaneously with soil $\mathrm{CO}_{2}$ efflux at the depth of 1.5 $\mathrm{cm}$. Data from the continuous measurements were used to determine the temperature sensitivity of soil $\mathrm{CO}_{2}$ efflux during the periods of individual manual measurement periods.

Soil $\mathrm{CO}_{2}$ efflux $\left(\mathrm{R}_{s}\right)$ from the continuous measurements by the automated system from one week containing the measurement campaign was plotted against soil temperature (Temp) and this was expressed by an exponential regression curve with the regression equation (eqn. 1):

$$
R_{S}=\beta \cdot e^{\alpha \cdot T e m p}
$$

where $\alpha$ and $\beta$ are the regression coefficients. Mean $\mathrm{Q}_{10}$ (the proportional change in $\mathrm{CO}_{2}$ efflux in relation to a $10{ }^{\circ} \mathrm{C}$ increase 
in temperature) from six chambers was calculated according to Lloyd \& Taylor (1994 eqn. 2):

$$
Q_{10}=e^{10 \cdot \alpha}
$$

being $\alpha$ the regression coefficient from eqn. 1 .

The $Q_{10}$ values were used to normalize soil $\mathrm{CO}_{2}$ efflux from each position of the liming experiment for the temperature 10 ${ }^{\circ} \mathrm{C}\left(\mathrm{R}_{10}\right)$ according to the following equation (eqn. 3):

$$
R_{10}=\frac{R_{s}}{Q_{10}^{\frac{T e m p-10}{10}}}
$$

\section{Laboratory determination of soil properties}

Laboratory analyses were performed in autumn 2016. The basal soil respiration (soil native $\mathrm{CO}_{2}$ release) was determined according to the soil analyses guidelines published by the Central Institute for Supervising and Testing in Agriculture (Zbíral 2016) and the International Organization for Standardization (ISO-16072 2002). The measurement was performed using the $\mathrm{YL}$ $6500 \mathrm{CC}^{\oplus}$ gas chromatograph (Soft Clarity Next Generation, YL Instruments Ltd., Anyang, Korea). The incubation was carried out for 24 hours at a constant temperature of $22{ }^{\circ} \mathrm{C}$. The $\mathrm{CO}_{2}$ concentration was determined using an all-purpose detector PDD (Pulsed Discharge Detector).

Microbial biomass carbon ( $\mathrm{Cmic}$ ) was assessed using the fumigation-extraction method according to Vance et al. (1987) and Joergensen (1995). The samples were analysed as fumigated (24-hour chloroform fumigation) and as non-fumigated. The organic carbon was extracted from all the samples with $0.5 \mathrm{M} \mathrm{K}_{2} \mathrm{SO}_{4}$, and the $C$ concentration was analysed by wet combustion (Yakovchenko \& Sikora 1998). Briefly, a mineralization mixture consisting of $25 \mathrm{M}$ $\mathrm{K}_{2} \mathrm{Cr}_{2} \mathrm{O}_{7}, 95 \% \mathrm{H}_{2} \mathrm{SO}_{4}$ and distilled water was added to the leachate. Mineralization occurred at $135{ }^{\circ} \mathrm{C}$ for 40 minutes. The soil extract absorbance was measured spectrophotometrically at a wavelength of 340 $\mathrm{nm}$.

The metabolic quotient $\left(\mathrm{qCO}_{2}\right)$ was calculated according to ISO-16072 (2002), with $\mathrm{qCO}_{2}\left[\mu \mathrm{g} \mathrm{C}_{-} \mathrm{CO}_{2} \mathrm{mg} \mathrm{Cmic} \mathrm{Ch}^{-1}\right]=$ basal respi-

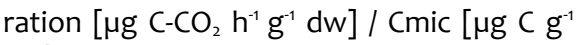
$\mathrm{dw}]$.

Soil $\mathrm{pH}$ was determined according to ISO/DIS-10390 (1992). It was assessed as both active $\left(\mathrm{pH} / \mathrm{H}_{2} \mathrm{O}\right)$ and exchangeable $(\mathrm{pH} / \mathrm{KCl})$ in water or $1 \mathrm{M} \mathrm{KCl}$, respectively, for the air-dried soil samples for a soil:eluate ratio of 1:5 (horizon $\mathrm{H}$ ) and 1:2.5 (horizon $A$ ). For the measurement, a glass electrode WTW SenTix $81^{\mathrm{TM}}$ (Thermo Fisher Scientific, Whaltham, MS, USA) combined with a fluid electrolyte and temperature sensor was used.

\section{Statistical analysis}

Analysis of variance (ANOVA) and Fisher's LSD test were performed using the software package Statistica ${ }^{\circledast}$ ver. 12 (StatSoft, Tulsa, OK, USA). One-way ANOVA at a significance level $\alpha=0.05$ (95\% confidence interval) was used for the comparison of soil properties of the individual liming variants. Post-hoc multiple comparisons was used in the case of significant differences among groups, using the Fisher's LSD test.

We tested statistical relations of $\mathrm{CO}_{2}$ efflux depending on either the categorical variables (lime doses, months) or the continuous variables (temperature, moisture).

Correlation and linear regression were carried out in the $\mathrm{R}$ language and environment version 3.3.1 (R Core Team 2018) using RStudio version 1.0.126. The correlation was verified via the Pearson's correlation coefficient using the function "cor()" at a significance level of 0.05 with a critical value of 0.413 for $n=21$.

We used a Bayesian version of linear mixed effect models to estimate the effect of limestone addition, time during vegetation season (expressed as the month of measurement) and two more covariates (soil temperature and soil moisture) as well as the significance of these effects. Linear mixed effect models were chosen as measurements for each month on the same plot were repeated (this information was stored in data using plot ID). Plot ID was specified as a random effect in all the models. Variables such as soil moisture, soil temperature, dolomitic limestone dosage and months were considered as fixed effects. All the fixed-effect explanatory variables were considered as continuous, and were scaled before analysis to reduce the multicollinearity of variables when adding the interaction term; scaled estimated coefficients are also directly comparable across models. Limestone dosage values were log transformed (natural logarithm) prior to analysis and the trend of the relationship between limestone dosage and $R_{10}$ was straighter after transformation. Limestone dosage values were back-transformed to the original values for the graphical presentation of the results. Control (zero addition) was kept as zero also for the transformed limestone dosage. We fitted several models, some with just one fixedeffect explanatory variables, others with their combination. We also included the interaction of months and limestone dosages as preliminary analysis revealed that the effect of limestone dosage on $\mathrm{R}_{10}$ could differ along the vegetation season. All the models were fitted using the package "brms" ver. 2.6.0 (Bürkner 2017) running in the $\mathrm{R}$ environment. Uninformative priors were chosen in all the models (defaults in brms). The fitted models were compared using LOO IC, which is an information criterion based on the "leave-one-out" crossvalidation method (Vehtari et al. 2017). Similarly to the well known Akaike Information Criterion (AIC), the model with smaller LOO IC has better fit to the data. Significance of the fixed-effect variables was evaluated using $95 \%$ highest definition intervals (HDI) whether zero value lies within credible values, i.e., whether it is within 95\% HDI (see more in Kruschke 2011). We also reported LOO adjusted version of Bayesian $R^{2}$ as a measure of goodness-of-fit. For the final model, estimates were reported for the version of the model with unscaled fixedeffect variables.

All the graphs were created using the package "ggplot2" version 2.2.1 (Wickham 2016).

\section{Results}

\section{Soil reaction after liming}

Liming influenced $\mathrm{pH} / \mathrm{H}_{2} \mathrm{O}$ in both horizons (Fig. 1a, Fig. 1b), but $\mathrm{pH} / \mathrm{KCl}$ was significantly affected only in the horizon $\mathrm{H}$. The $\mathrm{pH} / \mathrm{H}_{2} \mathrm{O}$ ratio increased in all the treatments compared to the control; statistical significance was detected in the treatments only in the $\mathrm{H}$ horizon $(\mathrm{p}=0.0032)$ at the doses

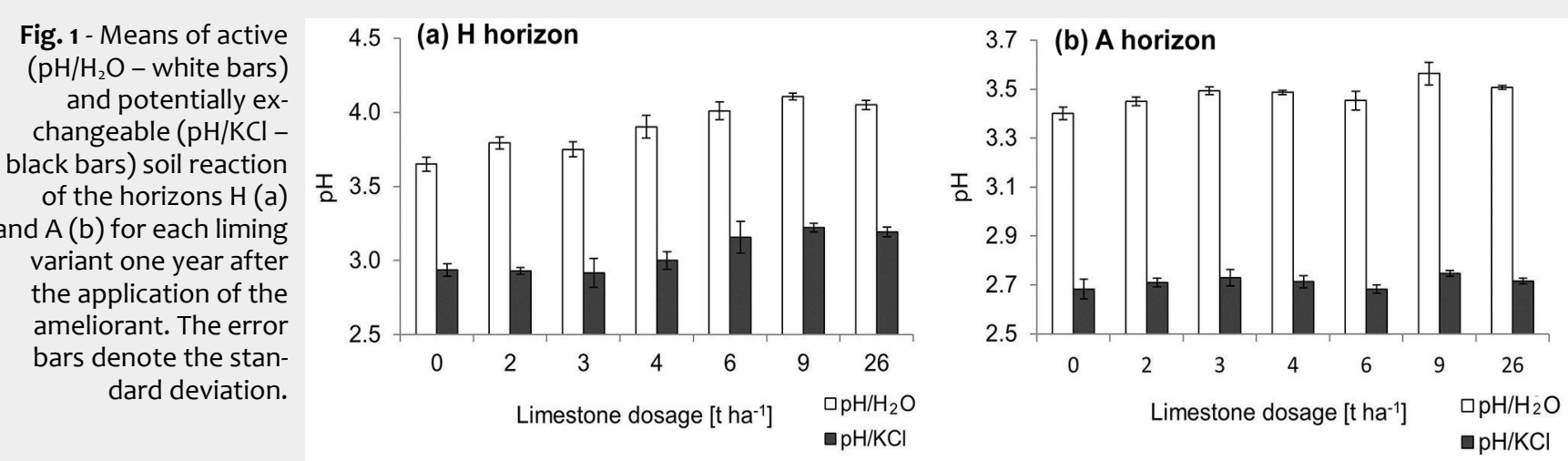




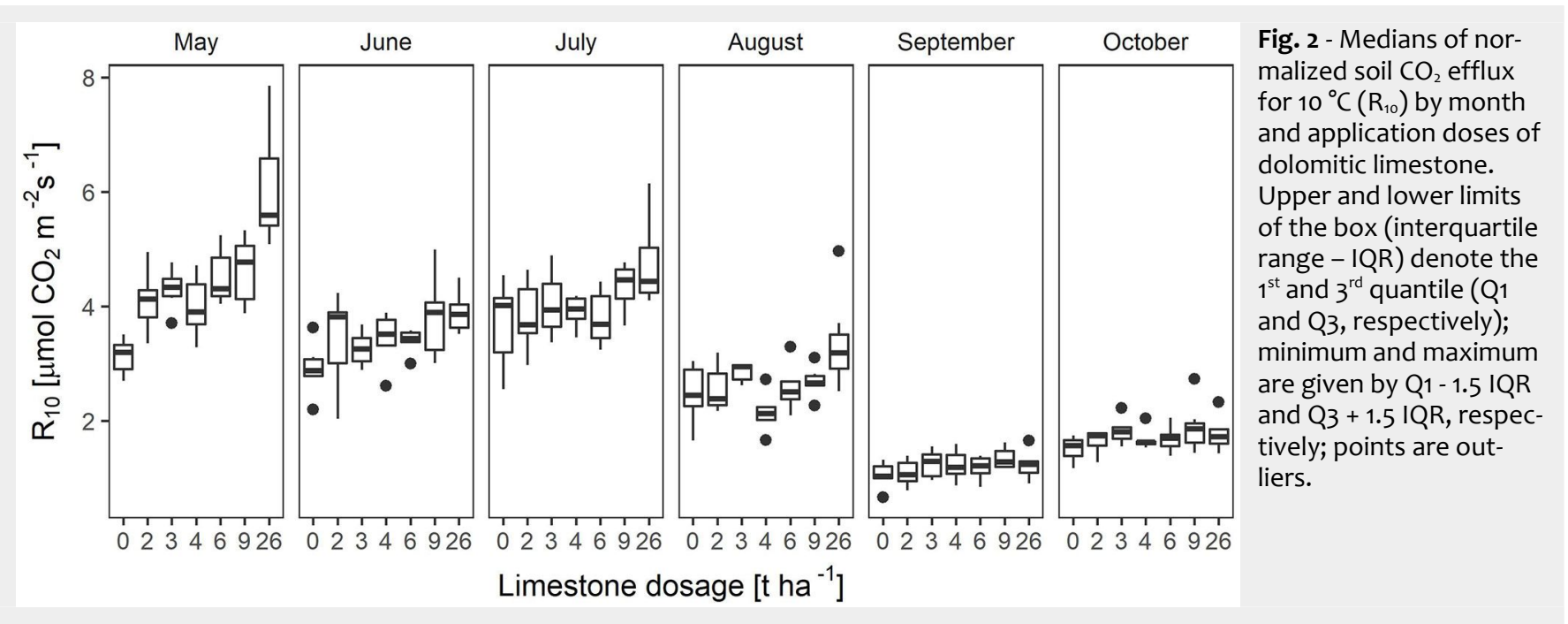

of $4(p=0.0236), 6(p=0.0028), 9(p=$ ber.

$0.0004)$ and $26 \mathrm{t} \mathrm{ha}^{-1}(\mathrm{p}=0.0013)$. The $\mathrm{pH} / \mathrm{KCl}$ ratio increased only in the $\mathrm{H}$ horizon, however without statistical significance. The highest $\mathrm{pH}$ increase in comparison with the non-limed area occurred within the $\mathrm{H}$ horizon the variant $9 \mathrm{t} \mathrm{ha}^{-1}$ $\left(\mathrm{pH} / \mathrm{KCl}: 0.29 ; \mathrm{pH} / \mathrm{H}_{2} \mathrm{O}: 0.46\right)$. Within the $\mathrm{A}$ horizon, the $\mathrm{pH}$ increase was very low in response to the ameliorant doses, but the $\mathrm{pH} / \mathrm{KCl}$ values remained almost unchanged after liming (Fig. 1b).

\section{In situ seasonal measurements}

Both soil temperature and moisture profoundly changed during the season. Mean soil temperature ranged 17.9 to $21.1^{\circ} \mathrm{C}$, except for October when it dropped to $7.0^{\circ} \mathrm{C}$. Soil moisture was the highest in May (18.5 $\%)$ and the lowest in September when it was only $3.7 \%$ (with a minimum of $1.8 \%$, which corresponds to almost dry soil). Otherwise, soil moisture ranged 11.9 to $15.4 \%$.

The seasonal pattern of monthly $R_{10}$ in all the treatments was characterised by the highest values in May and the lowest in September (Fig. 2). The most significant factor affecting $R_{10}$ during the season was the increasing drought at the end of summer. This fact was mostly evident in September when the lowest $R_{10}$ was recorded. In October, an increase in soil moisture resulted in a higher $\mathrm{R}_{10}$ compared to Septem-
During the observed period, the average $\mathrm{R}_{10}$ showed statistically significant differences between liming doses during the period May-August $(p<0.05)$. The largest differences in $R_{10}$ for the liming dosage were found in May ( $p<0.0001)$. In each month, $\mathrm{R}_{10}$ showed an upward trend with increasing liming intensity. The steepest gradient was found out in May, while the lowest was monitored in September and October (Tab. 2) when the soil $\mathrm{CO}_{2}$ efflux was more subjected to external factors caused by weather conditions than to liming. The exceptions were found in August at the dose of $4 \mathrm{t} \mathrm{ha}^{-1}$ and in September at the doses of 2 and $4 \mathrm{t} \mathrm{ha}^{-1}$, where the lowest $R_{10}$ of all the variants were observed. Overall, the lowest values were found out in September and only slightly higher in October. The overall dynamics of $R_{10}$ had a downward trend during the season and the highest liming effect was found in May with a 98\% increase at the extreme doses $\left(26 \mathrm{t} \mathrm{ha}^{-1}\right)$. The reference doses, which are the most frequently used in forestry $\left(2-4 \mathrm{t} \mathrm{ha}^{-1}\right)$, resulted in a $7-17 \%$ increase in $R_{10}$ in the allseason average with the lowest response at the dose of $4 \mathrm{t} \mathrm{ha}^{-1}$ (Tab. 2).

\section{Soil $\mathrm{CO}_{2}$ efflux under influence of} seasonal factors and treatments

Respiration was significantly affected by both categorical and continuous variables (Tab. 3). The influence of limestone dosage on the $\mathrm{CO}_{2}$ efflux was affected by external factors. The influence of liming alone was quite weak (M1), while the best fitting model was M11 which combines the limestone dosage, month of measurement and moisture. As both factors condition soil biological activity, the different effect of liming under the influence of seasonal dynamics lies either on moisture, which markedly decreased in September or temperature, which markedly decreased in October (reflected in model M11 by the interaction LimeVol $\times$ month).

The best fitted model M11 includes all the studied variables and the interaction LimeVol $\times$ month. Tab. 4 shows the relative influence of the scaled variables included in model M11, among which month had the strongest (negative) influence. In the measured season the most intensive $\mathrm{CO}_{2}$ efflux was in May and the weakest in October under the influence of different factors. The modelled influence of soil moisture on $\mathrm{CO}_{2}$ efflux, together with doses of lime and season (for months May, July and September) is shown in Fig. 3. An increase in $\mathrm{CO}_{2}$ efflux with increasing soil moisture (increasing intercept of the curves) is evident, as well as the steeper dependence of $\mathrm{CO}_{2}$ efflux on liming at the beginning of season (May), where the biological activity was unlimited

Tab. 2 - Mean $\mathrm{R}_{10}$ (in $\mu \mathrm{mol} \mathrm{CO} \mathrm{CO}^{-2} \mathrm{~s}^{-1}$ ) by month and doses of dolomitic limestone expressed as the percentage difference (perc) in the month vs. the control treatment ( $\mathrm{LimeVol}=0)$.

\begin{tabular}{cccccccccccccc}
\hline \multirow{2}{*}{$\begin{array}{c}\text { LimeVol } \\
\left(\mathrm{t} \mathrm{ha}^{-1}\right)\end{array}$} & \multicolumn{2}{c}{ May } & \multicolumn{2}{c}{ June } & \multicolumn{2}{c}{ July } & \multicolumn{2}{c}{ August } & \multicolumn{2}{c}{ September } & \multicolumn{2}{c}{ October } \\
\cline { 2 - 14 }$y$ & mean & perc & mean & perc & mean & perc & mean & perc & mean & perc & mean & perc \\
\hline 0 & 3.13 & 100.0 & 2.91 & 100.0 & 3.69 & 100.0 & 2.49 & 100.0 & 1.13 & 100.0 & 1.51 & 100.0 \\
\hline 2 & 4.09 & 130.8 & 3.41 & 117.1 & 3.85 & 104.5 & 2.56 & 102.9 & 1.09 & 97.1 & 1.64 & 108.7 \\
\hline 3 & 4.30 & 137.6 & 3.26 & 112.0 & 4.04 & 109.6 & 2.85 & 114.3 & 1.24 & 110.2 & 1.82 & 120.3 \\
\hline 4 & 4.00 & 127.9 & 3.44 & 118.1 & 3.92 & 106.2 & 2.15 & 86.2 & 1.10 & 97.9 & 1.60 & 105.6 \\
\hline 6 & 4.52 & 144.7 & 3.40 & 116.7 & 3.79 & 102.9 & 2.57 & 103.3 & 1.18 & 104.9 & 1.73 & 114.6 \\
\hline 9 & 4.63 & 148.0 & 3.79 & 130.0 & 4.35 & 117.9 & 2.69 & 107.8 & 1.35 & 119.4 & 1.88 & 124.6 \\
\hline 26 & 6.18 & 197.6 & 3.89 & 133.4 & 4.75 & 128.8 & 3.36 & 134.8 & 1.22 & 108.7 & 1.77 & 117.2 \\
\hline
\end{tabular}


Tab. 3 - Effect of dosage of dolomitic limestone and other variables (month, moisture and temperature) on $\mathrm{R}_{10}$. All the fitted models are Bayesian mixed effect models with random effect of plot ID. Explanatory variables were scaled before fitting, so the estimated parameters are on scaled scale. (LOO-ajd $\mathrm{R}^{2}$ ): LOO adjusted Bayesian $\mathrm{R}^{2}$; (LOO IC): information criterion - models with lower value of LOO IC had better fit; SD (ID): standard deviation among random effects in the scale of $\mathrm{CO}_{2}$ efflux. Models are ordered according their LOO IC from the best-fitting model to the worst one. Variables abbreviations: (LimeVol_In): dosage of dolomitic limestone transformed by natural logarithm; (month): month of measurements; (Moist): soil volumetric moisture; (Temp): soil temperature.

\begin{tabular}{|c|c|c|c|c|}
\hline Model No. & Predictor with estimated parameters & LOO-adj R ${ }^{2}$ & LOO IC & SD(ID) \\
\hline M11 & $2.92+0.18 \cdot$ LimeVol_ln $-0.85 \cdot$ month $+0.47 \cdot$ Moist $-0.20 \cdot$ LimeVol_ln:month & 0.819 & 474.2 & 0.30 \\
\hline M9 & $2.92+0.18 \cdot$ LimeVol_ln $-0.86 \cdot$ month $+0.47 \cdot$ Moist & 0.787 & 517.2 & 0.28 \\
\hline M7 & $2.92-0.85 \cdot$ month $+0.5 \cdot$ Moist & 0.786 & 519.9 & 0.33 \\
\hline M10 & $2.91+0.30 \cdot$ LimeVol_In $-1.19 \cdot$ month $-0.22 \cdot$ Temp $-0.21 \cdot$ LimeVol_In:month & 0.726 & 588.5 & 0.16 \\
\hline M8 & $2.91+0.30 \cdot$ LimeVol_ln $-1.19 \cdot$ month $-0.22 \cdot$ Temp & 0.670 & 614.9 & 0.14 \\
\hline M5 & $2.91-1.06 \cdot$ month $+0.28 \cdot$ LimeVol_ln & 0.683 & 628.9 & 0.13 \\
\hline M6 & $2.92-1.19 \cdot$ month $-0.20 \cdot$ Temp & 0.680 & 632.3 & 0.34 \\
\hline M2 & $2.91-1.06 \cdot$ month & 0.663 & 645.7 & 0.33 \\
\hline M12 & $2.88+0.07 \cdot$ LimeVol_ln $+0.60 \cdot$ Temp $+0.91 \cdot$ Moist $+0.15 \cdot$ LimeVol_ln:Moist & 0.649 & 658.5 & 0.32 \\
\hline M4 & $2.92+0.86 \cdot$ Moist & 0.407 & 803.8 & 0.16 \\
\hline M3 & $2.90+0.55 \cdot$ Temp & 0.158 & 902.6 & 0.11 \\
\hline M1 & $2.90+0.29 \cdot$ LimeVol_ln & 0.028 & 941.1 & 0.08 \\
\hline
\end{tabular}

by moisture and temperature. Therefore, equal response of biological activity on amelioration during the whole season cannot be expected.

\section{Soil microbial characteristics one year after liming}

In the soil samples collected for soil respiration no carbonates were detected, hence all $\mathrm{CO}_{2}$ measured during the analysis comes from respiration. In one year, the effect of liming was evident within both the $\mathrm{H}$ and $\mathrm{A}$ horizons (Fig. 4a, Fig. 4b).

For the $\mathrm{H}$ horizon, apart from the $26 \mathrm{t} \mathrm{ha}^{-1}$ treatment, the values of soil respiration tended to increase depending on the in-
Tab. 4 - Scaled and unscaled parameter estimates for final model M11 together with their highest density intervals (HDI). HDI are Bayesian alternative to confidence intervals with either scaled or unscaled variables. (LimeVol_In): dosage of dolomitic limestone transformed by natural logarithm; (month): month of measurements; (Moist): soil volumetric moisture.

\begin{tabular}{|c|c|c|c|c|c|c|}
\hline \multirow[b]{2}{*}{ Variable } & \multicolumn{3}{|c|}{ Scaled variables $(\mu=0 ; \sigma=1)$} & \multicolumn{2}{|c|}{ Unscaled variables } & \multirow[b]{2}{*}{$\begin{array}{l}\text { Upper } \\
95 \% \text { HDI }\end{array}$} \\
\hline & Estimate & $\begin{array}{l}\text { Lower } \\
95 \% \mathrm{HDI}\end{array}$ & $\begin{array}{l}\text { Upper } \\
95 \% \text { HDI }\end{array}$ & Estimate & $\begin{array}{l}\text { Lower } \\
95 \% \text { HDI }\end{array}$ & \\
\hline intercept & 2.92 & 2.81 & 3.02 & 3.980 & 3.409 & 4.559 \\
\hline LimeVol_In (A) & 0.18 & 0.07 & 0.29 & 1.075 & 0.793 & 1.356 \\
\hline Month (B) & -0.85 & -0.92 & -0.78 & -0.322 & -0.388 & -0.256 \\
\hline Moist & 0.47 & 0.40 & 0.55 & 0.085 & 0.071 & 0.099 \\
\hline$A \times B$ interaction & -0.20 & -0.26 & -0.14 & -0.119 & -0.155 & -0.083 \\
\hline
\end{tabular}

Fig. 3 - Graphic results of the Bayesian modelling. Model M11 values of $\mathrm{CO}_{2}$ efflux $\left(\mathrm{R}_{10}, y\right.$-axis) in dependence on doses of lime ( $x$-axis), in three categories of soil moisture $(5,12.5$ and $20 \mathrm{vol}$. \%) and three selected months (May, July and September). The grey belts denote $95 \%$ confidence interval.

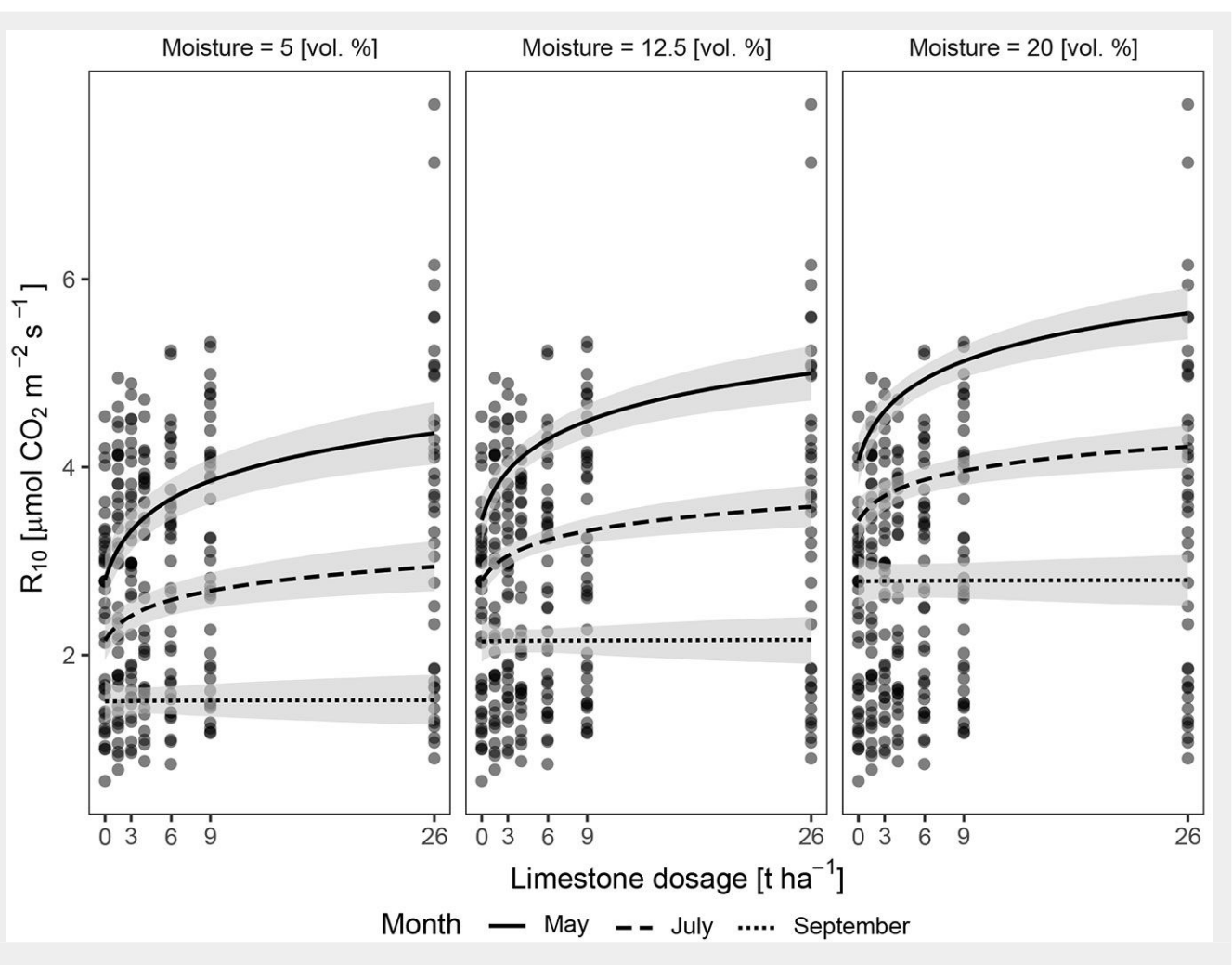




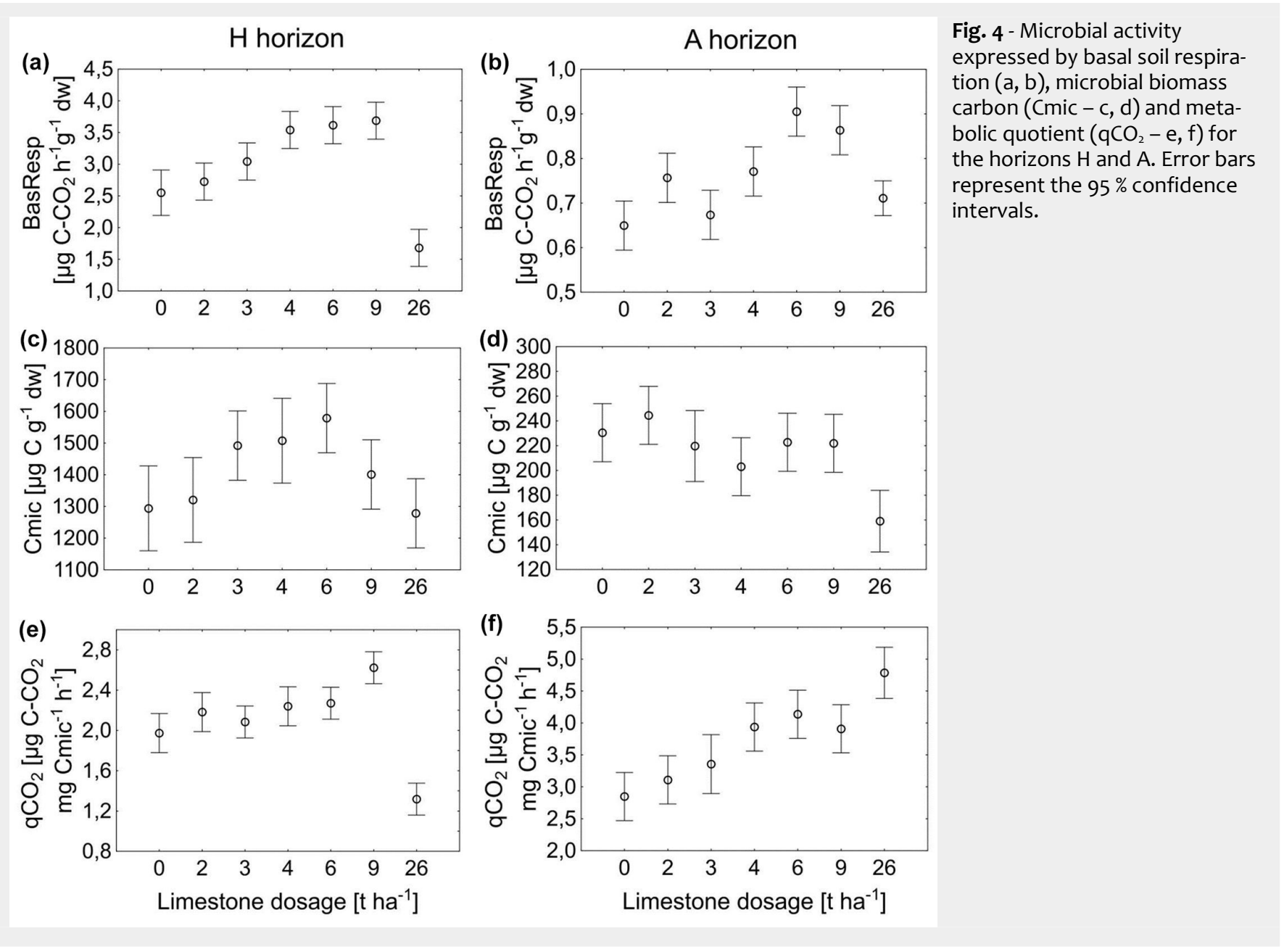

creasing amounts of the ameliorant. Unlike the $\mathrm{CO}_{2}$ efflux measured from the soil surface, the $26 \mathrm{t} \mathrm{ha}^{-1}$ variant unexpectedly reached the lowest soil respiration level. The highest values were reached for the $9 \mathrm{t}$ ha ${ }^{-1}$ limed area.

The lowest values in the $A$ horizon were reached in the control subplot; compared to them, the different ameliorant doses caused an increase in soil respiration activity. However, the most heavily limed area showed significantly lower soil respiration than did the variants at 9 and $6 \mathrm{t} \mathrm{ha}^{-1}$.

The microbial biomass carbon ( $\mathrm{Cmic}$ ) amount was dependent on ameliorant doses in both horizons. With an increasing ameliorant dose, there is a gradual increase in the $\mathrm{Cmic}$ values in the humus horizon, followed by a significant decrease at the doses of 9 and $26 \mathrm{t} \mathrm{ha}^{-1}$, which are even lower than the control (Fig. 4C). In the A horizon, Cmic decreased with increasing the ameliorant dose (except for the variant $2 \mathrm{t} \mathrm{ha}^{-1}$ where the increase was non-significant) to the lowest values in the most heavily limed treatment. Therefore, in the control, immediately after the application of the $2 \mathrm{t} \mathrm{ha}^{-1}$ variant, it reaches the highest values (Fig. 4d).

In both horizons $\mathrm{H}$ and $\mathrm{A}$, the soil respiration was significantly affected by $\mathrm{Cmic}$, (Pearson's $r=0.721, p<0.05$; and $r=0.517$, $\mathrm{p}<0.05$, respectively).
The metabolic quotient $\left(\mathrm{qCO}_{2}\right)$ was found to be higher in the A-horizon than in the $\mathrm{H}$ horizon (Fig. 4e, Fig. 4f). Moreover, all the treated subplots showed the increased $\mathrm{qCO}_{2}$ values in comparison with the control, except for the variant $26 \mathrm{t} \mathrm{ha}^{-1}$ in the $\mathrm{H}$ horizon (Fig. 4e), where a remarkable decrease in $\mathrm{qCO}_{2}$ was observed.

\section{Discussion}

The practice of limestone application may affect various aspects of soil properties and microbial activity. Andersson \& Nilsson (2001) demonstrated an increase in $\mathrm{pH}$ of the upper soil layers over a period of 12 or more years after the liming doses of $8.8 \mathrm{t}$ $\mathrm{ha}^{-1}$. Conversely, lower $\mathrm{pH}$ values in mineral soil 4 years after liming at the dose of 3.25 $\mathrm{t} \mathrm{ha}^{-1}$ are reported by Lundström et al. (2003). The short-term effect of the soil pH modification is documented by Vavríček \& Kučera (2016) who reported a minimum impact on $\mathrm{pH} 15$ years after the application dosage of $26 \mathrm{t} \mathrm{ha}^{-1}$. By contrast, McKie et al. (2006) discussed the potential risks connected with the inappropriately high doses of limestone and consequent substantial $\mathrm{pH}$ changes in the humus layer. Soil buffering capacity was demonstrated in our study, when one year after liming there was only a slight $\mathrm{pH}$ increase in the two observed horizons ( 0.4 in $\mathrm{H}$ horizon, 0.1 in $\mathrm{A}$ horizon), especially when thick humus lay- ers leading to moder and mor humus forms evolve - a situation typical of most of the Norway spruce stands (McCauley et al. 2009).

Both methods applied in this study for determining soil respiration demonstrated the dependence of this parameter on the individual doses of ameliorant. In particular, basal soil respiration in organic horizons showed an increase when increasing the ameliorant dose (Nilsson et al. 2001, McKie et al. 2006), except for the $26 \mathrm{t} \mathrm{ha}^{-1}$ treatment, which decreased to values even lower than the non-limed treatments. These results are inconsistent with the general expectations and it is possible that extreme ameliorant doses may have a different impact on soil biological properties compared to lower doses. However, the literature does not provide any examples of the inhibition of soil biological activity due to the application of extreme doses of the ameliorant. Moreover, our results from field measurements did not reveal any decrease in soil $\mathrm{CO}_{2}$ efflux under the highest limestone dosage. The possible cause is a significant alteration of the microbial community due to the substantial chemical impact (similar to the findings by Shah et al. 1990), leading to changes both in the total volume of microbial biomass and in the related microbial activity.

The respiration of the plant root system is 
also an important factor affecting the resulting soil $\mathrm{CO}_{2}$ efflux measured in the field (Raich \& Tufekciogul 2000). Comstedt et al. (2011) revealed that respiration of the rhizosphere accounted for about $50 \%$ of the total soil $\mathrm{CO}_{2}$ efflux in a mature Norway spruce forest. According to Hanson et al. (2000) the proportion of root respiration can be $10-90 \%$ of total soil respiration, depending on vegetation type and season. However, the subdivision of the total soil respiration in root respiration (autotrophic) and soil microorganism respiration (heterotrophic - Kuzyakov \& Larionova 2005) is still unclear (Bhupinderpal et al. 2003, Baggs 2006) and often yielded different results (Bond-Lamberty et al. 2004). Our study dealt with the total soil respiration ( $\mathrm{CO}_{2}$ efflux) which characterises the response of the whole soil ecosystem in our study.

Although field measurement of $\mathrm{CO}_{2}$ efflux from soil under natural conditions allows for the respiratory activity dynamics to be monitored during the season, the effects of external environmental factors can also be incorporated. These factors substantially drive the temporal (from daily to seasonal) variability of soil $\mathrm{CO}_{2}$ efflux and include mainly soil temperature and moisture (Davidson et al. 1998). In our study, the reduction of normalized $\mathrm{CO}_{2}$ efflux at $10{ }^{\circ} \mathrm{C}\left(\mathrm{R}_{10}\right)$ under soil moisture in September was observed, and the corresponding soil moisture was only $3.7 \%$. Under such conditions, soil $\mathrm{CO}_{2}$ efflux is almost independent on temperature, and soil moisture becomes the driving factor (Yuste et al. 2003). The $R_{10}$ decline in October can be associated with the decrease in microbial biomass and activity at the end of the season and with permanent low temperatures. Moreover, the increase in respiration during warmer months could lead to the significant interaction between $R_{10}$ and temperature observed in this study (Rigobelo \& Nahas 2004).

The largest differences in field measurements were observed for the treatment 26 $t$ ha $^{-1}$ in May, when $R_{10}$ increased by $97.6 \%$ compared to the control. However, this enormous difference decreased during the season, and by September, the increase was only $8.7 \%$ (Tab. 2). Lundström et al. (2003) reports a 35\% increase in soil respiration 14 years after liming the spruce stands at the dose of $8.75 \mathrm{t} \mathrm{ha}^{-1}$ compared to the control. In our case, the average $\mathrm{R}_{10}$ measured in May increased by $32.4 \%$ after $9 \mathrm{t}$ $\mathrm{ha}^{-1}$ liming; the lowest increase in this variant was detected in August (7.8\%).

In some cases, the expected liming effect on microbial soil activity is also reflected in the increase in the carbon microbial biomass Cmic (Aye et al. 2016) and metabolic quotient $\mathrm{qCO}_{2}$ (Lorenz et al. 2001). On the other hand, Priha \& Smolander (1994) reported no or only minimal changes in the amount of microbial biomass after liming. In our study, we found that the response on liming may differ between the individual horizons and also in dependence on limestone dosage. In the $\mathrm{H}$ horizon, $\mathrm{Cmic}$ tended to increase after liming, except for the dosage of $26 \mathrm{t} \mathrm{ha}^{-1}$. On the contrary, Cmic slightly decreased after liming the $A$ horizon except for the dosages of $2 \mathrm{t} \mathrm{ha}^{-1}$. Therefore, it may be assumed that in the $A$ horizon, liming acted as an inhibitor, to a certain extent, and the $\mathrm{Cmic}$ decreased as the dose of dolomitic limestone increased.

The effect of various liming doses on the metabolic quotient $\left(\mathrm{qCO}_{2}\right)$ is expressed as an increase in $\mathrm{qCO}_{2}$ values according to increasing of ameliorant doses. This can be related to bacterial communities reacting to changes in soil chemistry (Bauhus \& Khanna 1999). However, the exception is the $26 \mathrm{t} \mathrm{ha}^{-1}$ variant within the $\mathrm{H}$ horizon, which showed $33.2 \%$ decrease compared to the control. In this case, the extreme doses could lead to a temporal inhibition of microbial activity $\left(\mathrm{qCO}_{2}\right)$.

Despite the current application of dolomitic limestone on forest soils, it may be discussed whether liming is a suitable practice to improve soil chemistry. Liming results in an increase of soil biological activity and hence in an increase in mineralization of organic layers. Although this is confirmed by the presented results, there are still unknown aspects regarding the consequences of liming. The following questions still need to be answered: (i) what is the proportion of autotrophic/heterotrophic respiration? (ii) are we able to measure how fast is the organic layer mineralization? (iii) what are the consequences of liming on long-term plant nutrition and soil water regime?

\section{Conclusions}

In general, liming increased soil respiration in our experimental forest stand, and this was confirmed by both in situ measurements and laboratory analyses. However, the effect of liming in situ was mitigated by environmental conditions such as drought or low temperatures.

The hypothesis that the effect of liming will increase with limestone dosage was fully confirmed only for in situ measurements of soil $\mathrm{CO}_{2}$ efflux and $\mathrm{qCO}_{2}$ in A horizon. For the basal respiration, a decrease for the dose of $26 \mathrm{t} \mathrm{ha}^{-1}$ was observed, with values in the $\mathrm{H}$ horizon even lower than in the control.

In the $\mathrm{H}$ horizon, liming increased the amount of microbial biomass, and a gradual inhibition of microbial development was observed at the highest ameliorant doses. In contrast, microbial biomass development in the A-horizon was inhibited after liming and this inhibition increased with the ameliorant dose.

Our results confirm that the dose of ameliorant commonly used in forest management $\left(3 \mathrm{t} \mathrm{ha}^{-1}\right)$ significantly increases the microbial activity of forest soil even one year after liming. This may accelerate the mineralization of soil organic material and lead to a decrease in soil quality. Future studies based on soil respiration measurement under controlled laboratory conditions will provide a better understanding of the potential response of soil microorganisms to changes in soil chemistry under optimal conditions.

\section{List of abbreviations}

(BasResp): basal respiration; (BS): base saturation; (CEC): cation exchange capacity; (Cmic): microbial biomass carbon; (Corg): organic (oxidizable) carbon content; $(\mathrm{C} / \mathrm{N})$ : carbon-to-nitrogen ratio; (dw): dry weight; (HDI): highest density interval; (LimeVol): liming variant; (LOO-ajd $\mathrm{R}^{2}$ ): adjusted $\mathrm{R}^{2}$; (LOO IC): LOO information criterion; (Moist): soil moisture; $\left(\mathrm{pH} / \mathrm{H}_{2} \mathrm{O}\right)$ : active soil $\mathrm{pH} ;(\mathrm{pH} / \mathrm{KCl})$ : exchangeable soil $\mathrm{pH}$; $\left(\mathrm{qCO}_{2}\right)$ : metabolic quotient; $\left(\mathrm{Q}_{10}\right)$ : the proportional change in $\mathrm{CO}_{2}$ efflux in relation to a $10{ }^{\circ} \mathrm{C}$ increase in temperature; $\left(\mathrm{R}_{10}\right)$ : normalized soil $\mathrm{CO}_{2}$ efflux for $10{ }^{\circ} \mathrm{C}$; $\left(\mathrm{R}_{\mathrm{s}}\right)$ : soil $\mathrm{CO}_{2}$ efflux; (sd): standard deviation; SD (ID): estimation of variability among random effects in scale of $\mathrm{CO}_{2}$ efflux; (Temp): soil temperature.

\section{Acknowledgments}

The work was supported by a Specific University Research Fund of the FFWT Mendel University in Brno (project No. LDF_VP_2016026), and projects QK1920328

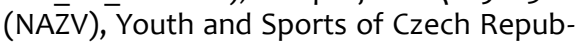
lic within the National Sustainability Program I (NPU I), grant number LO1415.

\section{References}

Andersson S, Nilsson I (2001). Influence of pH and temperature on microbial activity, substrate availability of soil-solution bacteria and leaching of dissolved organic carbon in a mor humus. Soil Biology and Biochemistry 33: 11811191. - doi: 10.1016/S0038-0717(01)00022-0

Augusto L, Ranger J, Binkley D, Rothe A (2002). Impact of several common tree species of European temperate forests on soil fertility. Annals of Forest Sciences 59: 233-253. - doi: 10.105 1/forest:2002020

Aye NS, Sale PWG, Tang C (2016). The impact of long-term liming on soil organic carbon and aggregate stability in low-input acid soils. Biology and Fertility of Soils 52: 697-709. - doi: 10.1007/ s00374-016-1111-y

Bååth E, Anderson TH (2003). Comparison of soil fungal/bacterial ratios in a $\mathrm{pH}$ gradient using physiological and PLFA-based technique. Soil Biology and Biochemistry 35: 955-963. - doi: 10.1016/S0038-0717(03)00154-8

Baggs L (2006). Partitioning the components of soil respiration: a research challenge. Plant and Soil 284: 1-5. - doi: 10.1007/s11104-006-0047-7 Bauhus J, Khanna PK (1999). The significance of microbial biomass in forest soils. In: "Going Underground - Ecological Studies in Forest Soils" (Rastin N, Bauhus J eds). Research Signpost, Trivandrum, India, pp. 77-110.

Berryman ER, Barnard HR, Adams HR, Burns MA, Gallo E, Brooks PD (2015). Complex terrain alters temperature and moisture limitations of forest soil respiration across a semiarid to subalpine gradient. Journal of Geophysical Re- 
search: Biogeosciences 120: 707-723. - doi: 10.10 02/2014JG002802

Bhupinderpal S, Nordgren A, Ottosson Löfvenius $M$, Högberg $M N$, Mellander $P E$, Högberg $P$ (2003). Tree root and soil heterotrophic respiration as revealed by girdling of boreal Scots pine forest: extending observations beyond the first year. Plant, Cell and Environment 26 (8): 1287-1296. - doi: 10.1046/j.1365-3040.2003.0 1053.x

Binkley D, Högberg P (2016). Tamm review: revisiting the influence of nitrogen deposition on Swedish forests. Forest Ecology and Management 368: 222-239. - doi: 10.1016/j.foreco.2016. 02.035

Bond-Lamberty B, Wang C, Gower ST (2004). A global relationship between the heterotrophic and autotrophic components of soil respiration? Global Change Biology 10: 1756-1766. - doi: 10.1111/j.1365-2486.2004.00816.x

Bürkner PC (2017). brms: an R package for Bayesian multilevel models using stan. Journal of Statistical Software 80: 1-28.

Comstedt D, Bostrom B, Ekblad A (2011). Autotrophic and heterotrophic soil respiration in a Norway spruce forest: estimating the root decomposition and soil moisture effects in a trenching experiment. Biogeochemistry 104: 121-132. - doi: 10.1007/s10533-010-9491-9

Corre MD, Beese FO, Brumme R (2003). Soil nitrogen cycle in high nitrogen deposition forest: changes under nitrogen saturation and liming. Ecological Applications 13: 287-298. - doi: 10.189 0/1051-0761(2003)013[0287:SNCIHN]2.0.CO;2

Darenova E, Cater M, Pavelka M (2016). Different harvest intensity and soil $\mathrm{CO}_{2}$ efflux in sessile oak coppice forests. iForest 9: 546-552. - doi: 10.3832/ifor1773-009

Davidson EA, Belk E, Boone RD (1998). Soil water content and temperature as independent or confounded factors controlling soil respiration in a temperate mixed hardwood forest. Global Change Biology 4: 217-227. - doi: 10.1046/ j.1365-2486.1998.00128.x

IUSS-WRB (2015). World reference base for soil resources 2014. International soil classification system for naming soils and creating legends for soil maps. FAO-IUSS Working Group WRB, World Soil Resources Reports no. 106, FAO, Rome, Italy, pp. 192.

Frank J, Stuanes AO (2003). Short-term effects of liming and vitality fertilization on forest soil and nutrient leaching in a Scots pine ecosystem in Norway. Forest Ecology and Management 176: 371-386. - doi: 10.1016/S0378-1127(02)00285

Hanson PJ, Edwards NT, Garten CT, Andrews JA (2000). Separating root and soil microbial contributions to soil respiration: a review of methods and observations. Biogeochemistry 48: 115146. - doi: 10.1023/A:1006244819642

Hindar A, Wright RF, Nilsen P, Larssen T, Hgberget $R$ (2003). Effects on stream water chemistry and forest vitality after whole-catchment application of dolomite to a forest ecosystem in southern Norway. Forest Ecology and Management 180: 509-525. - doi: 10.1016/S0378-1127 (02)00647-3

Huber C, Baier R, Göttlein A, Weis W (2006). Changes in soil, seepage water and needle chemistry between 1984 and 2004 after liming an N-saturated Norway spruce stand at the Höglwald, Germany. Forest Ecology and Management 233: 11-20. - doi: 10.1016/j.foreco.2006. 05.058

Hunová I, Ostatnická J (2004). Ambient air quality and deposition trends at rural stations in the Czech Republic during 1993-2001. Atmospheric Environment 38: 887-898. - doi: 10.1016/j.atmos env.2003.10.032

ISO-10693 (1995). Soil quality - determination of carbonate content - volumetric method. International Organization for Standardization, Geneve, Switzerland, pp. 7.

ISO-16072 (2002). Soil quality - laboratory methods for determination of microbial soil respiration. International Organization for Standardization, Geneve, Switzerland, pp. 19.

ISO/DIS-10390 (1992). Soil quality - determination of $\mathrm{pH}$. International Organization for Standardization, Geneve, Switzerland, pp. 112-114.

Joergensen RG (1995). The fumigation extraction method for microbial biomass nitrogen. In: "Methods in Applied Soil Microbiology and Biochemistry" (Alef K, Nannipieri P eds). Academic Press, London, UK, pp. 188-390.

Kakei M, Clifford PE (2002). Short-term effects of lime application on soil properties and fineroot characteristics for a 9-year-old Sitka spruce plantation growing on a deep peat soil. Forestry 75: 37-50. - doi: 10.1093/forestry/75.1.37 Kruschke K (2011). Doing Bayesian data analysis. A tutorial introduction with $\mathrm{R}$ and $\mathrm{BUGS}\left(1^{\text {st }}\right.$ edn). Academic Press, Burlington, USA, pp. 529.

Kuzyakov Y, Larionova AA (2005). Root and rhizomicrobial respiration: a review of approaches to estimate respiration by autotrophic and heterotrophic organisms in soil. Journal of Plant Nutrition and Soil Science 168: 503-520. - doi: 10.1002/jpln.200421703

Lee CS, Moon JS, Cho YC (2007). Effects of soil amelioration and tree planting on restoration of an air-pollution damaged forest in South Korea. Water, Air, and Soil Pollution 179: 239-254. doi: 10.1007/s11270-006-9228-5

Lloyd J, Taylor JA (1994). On the temperaturedependence of soil respiration. Functional Ecology 8: 315-323. - doi: 10.2307/2389824

Löfgren S, Cory N, Zetterberg Z, Larsson PE, Kronnäs V (2009). The long-term effects of catchment liming and reduced sulphur deposition on forest soils and runoff chemistry in southwest Sweden. Forest Ecology and Management 258: 567-578. - doi: 10.1016/j.foreco.2009.04.030

Lorenz K, Feger KH, Kandeler E (2001). The response of soil microbial biomass and activity of a Norway spruce forest to liming and drought. Journal of Plant Nutrition and Soil Science 164: 9-19. - doi: 10.1002/1522-2624(200102)164:1<9:: AID-JPLN9>3.0.CO;2-Q

Lundström US, Bain DC, Taylor AFS, Van Hees PAW, Geibe CE, Holmström SJM, Melkerud PA, Finlay R, Jones DL, Nyberg L, Gustafsson JP, Riise $G$, Taustrand L (2003). Effects of acidification and its mitigation with lime and wood ash on forest soil processes in southern Sweden. A joint multidisciplinary study. Water, Air and Soil Pollution 3: 167-188. - doi: 10.1023/A:1024131615 011

Majdi H, Viebke CG (2004). Effects of fertilization with dolomite lime+PK or wood ash on root dis- tribution and morphology in a Norway Spruce stand in southwest Sweden. Forest Science 50: 802-809.

McCauley A, Jones C, Jacobsen J (2009). Soil pH and organic matter. Nutrient Management Modules 8, Montana State University Extension Service, Montana, USA, SKU 4449- 8: 1-12.

McKie BG, Petrin Z, Malmquist B (2006). Mitigation or disturbance? Effects of liming on macroinvertebrate assemblage structure and leaf litter decomposition in the humic streams of northern Sweden. Journal of Applied Ecology 43: 780-791. - doi: 10.1111/j.1365-2664.2006.0119 6. $\mathrm{x}$

Moravčík P, Cienciala E (2005). An overview of knowledge to reduce the impact of air pollution and soil acidification on forests. In: "Longterm acidification and nutrient degradation of forest soils - limiting factors of forestry today" (Hruška J, Cienciala E eds). Czech Geological Survey, Prague, Czech Republic, pp. 35-53.

Nilsson I, Andersson S, Valeur I, Persson T, Bergholm J, Wirén A (2001). Influence of dolomite lime on leaching and storage of $\mathrm{C}, \mathrm{N}$ and $\mathrm{S}$ in a Spodosol under Norway spruce (Picea abies (L.) Karst.). Forest Ecology and Management 146: 55-73. - doi: 10.1016/S0378-1127(00)00452-7

Paradelo R, Virto I, Cenu C (2015). Net effect of liming on soil organic carbon stocks: a review. Agriculture, Ecosystems and Environment 202: 98-107. - doi: 10.1016/j.agee.2015.01.005

Priha O, Smolander A (1994). Fumigation-extraction and substrate-induced respiration derived microbial biomass $\mathrm{C}$, and respiration rate in limed soil of Scots pine sapling stands. Biology and Fertility of Soils 17: 301-308. - doi: 10.1007/ BFo0383986

Raich JW, Tufekciogul A (2000). Vegetation and soil respiration: correlations and controls. Biogeochemistry 48: 71-90. - doi: 10.1023/A:100611 2000616

R Core Team (2018). R: a language and environment for statistical computing. R Foundation for Statistical Computing, Vienna, Austria. [online] URL: http://www.R-project.org/

Rigobelo EC, Nahas E (2004). Seasonal fluctuations of bacterial population and microbial activity in soils cultivated with Eucalyptus and $\mathrm{Pi}$ nus. Scientia Agricola 16: 88-93. - doi: 10.1590/ S0103-90162004000100015

Saarsalmi A, Tamminen P, Kukkola M, Levula T (2011). Effects of liming on chemical properties of soil, needle nutrients and growth of Scots pine transplants. Forest Ecology and Management 262: 278-285. - doi: 10.1016/j.foreco.2011. 03.033

Seibt G (1977). Ergebnisse einiger Kalkdüngungsversuche in Nordwestdeutschland [Results in experimental liming in Northeastern Germany]. Forstarchiv 48: 197-199.

Shah Z, Adamst WA, Haven CDV (1990). Composition and activity of the microbial population in an acidic upland soil and effects of liming. Soil Biology and Biochemistry 22: 257-263. - doi: 10.1016/0038-0717(90)90095-H

Srámek V, Fadrhonsová V, Jurkovská L (2014b). Supervision and quality control of lime application in forest stands. Certified methodology. Forestry and Game Management Research Institute, Strnady, Czech Republic, pp. 31.

Srámek V, Novotny R, Fiala P, Neudertová-Helle- 
brandová K, Reiniger D, Samek T, Cihák T, Fadrhonsová V (2014a). Forest liming in Czech Republic. The Ministry of Agriculture of the Czech Republic, Forestry and Game Management Research Institute, Prague, Czech Republic, pp. 91.

Vance ED, Brookes PC, Jenkinson DS (1987). An extraction method for measuring soil microbial biomass C. Soil Biology and Biochemistry 19: 703-707. - doi: 10.1016/0038-0717(87)90052-6

Vavríček D, Kučera A (2016). Some risk arising from broadcast aerial liming of forest ecosystems not only in Carpathian area. In: Proceedings of the Conference "The Carpathian Forests" (Holusova K ed). Bunc-Chriby (Czech Republic), 4-5 May 2016. The Forest Management Institute (FMI), Brandys nad Labem, Czech Republic, pp. 32-46.

Vehtari A, Gelman A, Gabry J (2017). Practical
Bayesian model evaluation using leave-one-out cross-validation and WAIC. Statistics and Computing 27: 1413-1432. - doi: 10.1007/s11222-0169696-4

Viewegh J, Kusbach A, Mikeska M (2003). Czech forest ecosystem classification. Journal of Forest Science 49: 85-93.

Weis W, Gruber A, Huber C, Göttlein A (2009). Element concentrations and storage in the aboveground biomass of limed and unlimed Norway spruce trees at Höglwald. European Journal of Forest Research 128: 437-445. - doi: 10.1007/s10342-009-0291-5

Wickham H (2016). ggplot2: Elegant graphics for data analysis. Springer-Verlag, New York, USA, pp. 260. [online] URL: http://books.google. com/books?id=XgFkDAAAQBAJ

Yakovchenko VP, Sikora $\amalg$ (1998). Modified dichromate method for determining low concen- trations of extractable organic carbon in soil. Communications in Soil Science and Plant Analysis 29: 421-433. - doi: 10.1080/0010362980936 9955

Yuste JC, Janssens IA, Carrara A, Meiresonne L, Ceulemans R (2003). Interactive effects of temperature and precipitation on soil respiration in a temperate maritime pine forest. Tree Physiology 23: 1263-1270. - doi: 10.1093/treephys/23.18. 1263

Zbíral J (2016). Stanoveni bazalni a substratem indukovane respirace metodou GC [Determination of basal and substrate-induced respiration by GC method]. Jednotné Pracovní Postupy Analýza Pud, UKZUZ, Czech Republic, pp. 5. [in Czech] [online] URL: http://eagri.cz/public/web/ file/453360/_31042._1_Stanoveni_bazalni_a_su bstratem indukovane respirace_metodou_GC. pdf 